1 ANALYTICAL SCIENCE

3 \& TECHNOLOGY

Vol. 25 No. 1, 25-32, 2012

http://dx.doi.org/10.5806/AST.2012.25.1.025

\title{
Analysis of sorbic acid in tea-drink using isotope dilution liquid chromatography tandem mass spectrometry (ID-LC/MS/MS)
}

\author{
Seonghee Ahn, Insun Lee ${ }^{1}$ and Byungjoo Kim ${ }^{\star}$ \\ Division of Metrology for Quality Life, Korea Research Institute of Standards and Science, \\ 267 Gajeong-Ro, Yuseong-gu, Daejeon 305-600, Korea \\ ${ }^{1}$ Dong-il SHIMAZU Corp. R\&D center, Ace High-End Tower, No. 1105, \\ Geumcheon-gu, Seoul 153-803, Korea \\ (Received December 29, 2011; Revised January 18, 2012; Accepted January 18, 2012)

\section{동위원소희석 액체 크로마토그래피-질량분석법을 \\ 이용한 차음료 중의 소르빈산의 분석} \\ 안성희 · 이인선 ${ }^{1} \cdot$ 김병주 \\ 한국표준과학연구원 삶의질 표준부, ${ }^{1 ㄷ ㅗ ㅇ ㅇ ㅣ ㄹ ~ ㅅ ㅣ ㅁ ㅏ ㅈ ㅡ ~}$ \\ (2011. 12. 29. 접수, 2012. 1. 18. 수정. 2012. 1. 18. 승인)
}

\begin{abstract}
Isotope dilution mass spectrometry (ID-MS) based on liquid chromatography tandem mass spectrometry (LC/MS/MS) was developed for the accurate determination of sorbic acid in tea-drink. An isotope analogue of sorbic acid, ${ }^{13} \mathrm{C}_{2}$-sorbic acid, was obtained by custom synthesis. MS was operated in the negative mode with selected reaction monitoring $(\mathrm{SRM})$ mode of $[\mathrm{M}-\mathrm{H}]^{-} \rightarrow\left[\mathrm{M}^{-} \mathrm{CO}_{2} \mathrm{H}\right]^{-}$channel at $\mathrm{m} / z 111 \rightarrow 67$ for sorbic acid and at $m / z 113 \rightarrow 68$ for its isotope analogue. Chromatographic separation was accomplished with a $\mathrm{C} 18$ column and an isocratic mobile phase of $55 \%$ of $50 \mathrm{mM}$ ammonium acetate $(\mathrm{pH} 4.5)$ and $45 \%$ of methanol. Homogeneous reference materials were prepared for validation of this method, including repeatability and reproducibility tests, by fortifying tea-drink with sorbic acid in our laboratory. Repeatability and reproducibility studies showed that the ID-LC/MS method is a reliable and reproducible method which provides less than $3.8 \%$ of relative standard deviation (RSD) for the analysis of sorbic acid.

요 약: 동위원소희석 액체크로마토그래피-탄뎀질량분석법을 이용하여 차음료 중의 소르빈산을 정밀하 게 측정하는 방법을 개발하였다. 소르빈산의 동위원소, ${ }^{13} \mathrm{C}_{2}$-소르빈산은 주문합성하여 구입하였다. 질량 분석기는 음이온 모드로 선택반응분석법 (Selected Reaction Monitoring mode)에서 수행하여, $[\mathrm{M}-\mathrm{H}]^{-}$이 온이 $\left[\mathrm{M}_{-}-\mathrm{CO}_{2} \mathrm{H}\right]^{-}$조각이온으로 가는 $m / z \quad 111 \rightarrow 67$ 와 ${ }^{13} \mathrm{C}_{2}$-소르빈산 $m / z \quad 113 \rightarrow 68$ 채널을 선택하여 분석 하였다. 분리는 C18 컬럼으로 수행되었으며, 암모니움 아세테이트용액 $(\mathrm{pH} 4.5) 55 \%$ 와 메탄올 $45 \%$ 로 이 동상을 구성하였다. 반복성과 재현성을 포함한 방법의 유효성 검토를 위하여 본 연구원에서 차음료에 소 르빈산을 강화하여 균질성있는 기준물질을 제조하였다. 반복성과 재현성 결과는 동위원소희석 액체크로 마토그래피-탄뎀질량분석법에 의한 소르빈산의 분석이 신뢰할만 하며 재현성 있는 방법임을 보여주었고, 기준물질들의 소르빈산의 농도는 $3.8 \%$ 의 표준편차를 보여주었다.
\end{abstract}

Key words: sorbic acid, ID-LC/MS, reference materials, expanded uncertainty

Corresponding author

Phone : +82-(0)42-868-5367 Fax : +82-(0)42-868-5800

E-mail : byungjoo@kriss.re.kr 


\section{Introduction}

Sorbic acid and its corresponding salts (sodium, potassium, and calcium) are commonly used as food preservatives because of their inhibitory and antibacterial activities against growth of yeast, moulds and fungi. They are generally considered as safe food preservatives for human consumption with an high (25 mg/kg) acceptable daily intake level. ${ }^{1}$ However, it was reported that sorbic acid and its salts exhibit weak genotoxic potential and chromosomal aberrations. ${ }^{24}$ Also, Sochin et al. ${ }^{5}$ reported that sorbic acid could induce erythma and edema of human skin. Thus, they are regulated by the maximum permitted concentrations in each type of food. For example, the maximum level of sorbic acid is $3.0 \mathrm{~g} / \mathrm{kg}$ in cheese, $2.0 \mathrm{~g} / \mathrm{kg}$ in processed meat product, $1.0 \mathrm{~g} / \mathrm{kg}$ in jam, and $0.2 \mathrm{~g} / \mathrm{kg}$ in fermented fruit drink in Korea (Korean Food Additives Codex). Thus, it is necessary to determine and monitor their levels in foodstuffs to ensure they are within the permitted limits.

There are a variety of analytical methods for the analysis of sorbic acid in foods. Traditional techniques such as titrimetry, ${ }^{6}$ colorimetry, ${ }^{7}$ and spectrophotometry, ${ }^{8}$ required complicated and labor intensive sample treatment procedures. Separation methods with various detection techniques such as GC-MS,,-10 HPLC-UV ${ }^{11-18}$ and capillary electrophoresis (CE)UV ${ }^{19-20}$ have been most widely used for the analysis of sorbic acid. However, GC methods required derivatization for sorbic acid and LC method with a UV detector was easily biased by contaminants or matrix interferences. In this respect, tandem mass spectrometry with LC separation (LC/MS/MS) is a promising method for accurate determination of sorbic acid in food stuffs without derivatization.

In this study, a method for accurate determination of sorbic acid was established using isotope dilutionliquid chromatography mass spectrometry (ID-LC/ MS). The ID-MS method has been known to provide reliable and reproducible results with overcoming the difficulties in correction of recovery during sample preparation and demonstrating high accuracy of measurement results. ${ }^{21-24}$ However, an isotope analogue of sorbic acid is not commercially available, thus we obtained its isotope analogue by custom synthesis. It is the first time to employ ID-LC/MS for sorbic acid analysis. The conditions of separation and electrospray ionization efficiency has to be optimized considering the $\mathrm{pKa}$ of sorbic acid ( $\mathrm{pKa}=$ 4.75). For the validation of this method, we prepared reference materials by fortifying tea-drinks with sorbic acid. The repeatability and reproducibility of the proposed method were tested with these reference materials.

\section{Experimental}

\subsection{Materials}

Sorbic acid (purity $99.00 \%$ ) was purchased from Dr. Ehrenstorfer (Augsburg, Germany) and used without any further purification. ${ }^{13} \mathrm{C}_{2}$-sorbic acid was obtained as a custom synthetic product from Chemizon (Sungnam, Korea) and its purity has been assigned to be $99 \%$ by a manufacturer. HPLC grade methanol was obtained from Burdick and Jackson (Muskegon, MI, USA) and ammonium acetate was from Aldrich (Milwaukee, WI, USA).

\subsection{Standard solutions}

Standard solutions were prepared and verified in our laboratory as described elsewhere. ${ }^{25-26}$ Briefly, four standard solutions of sorbic acid were gravimetrically prepared in water with sonicating at $50{ }^{\circ} \mathrm{C}$ for $2 \mathrm{hrs}$ to ensure the complete dissolvation of sorbic acid. One ${ }^{13} \mathrm{C}_{2}$-sorbic acid standard solution was prepared as the same way. Isotope ratio standard solutions (1:1 isotope ratio) were prepared by mixing each sorbic acid standard solution with the ${ }^{13} \mathrm{C}_{2}$ sorbic acid solution gravimetrically. Two isotope ratio standard solutions were prepared from each of the four sorbic acid standard solutions. We tested self-consistency within and among the standard solutions by inter-comparing the eight isotope ratio standards by LC/MS/MS. Based on the inter-comparing results, one isotope ratio solution was selected and used for further sample analysis. 


\subsection{Sample preparation}

We prepared homogeneous reference materials (RM) with known levels of sorbic acid by fortifying blank tea-drink which was obtained from a local market. The level of sorbic acid in the blank drink sample was tested to be below the detection limit of this method. From each RM bottle, $0.5 \mathrm{~g}$ of subsample was spiked with an appropriate amount of the ${ }^{13} \mathrm{C}_{2}$-sorbic acid solution to make 1:1 isotope ratio and then filtered by using a nylon membrane filter $(0.2 \mu \mathrm{m}$, Whatman, UK). This sample was analyzed by LC/MS/MS without further clean-up or extraction procedures.

\section{$2.4 \mathrm{LC} / \mathrm{MS}$ analysis}

For the ID-LC/MS analysis of the samples, an API 2000 mass spectrometer from Applied Biosystems (Forster City, CA, USA) which is interfaced with an 1100 Series LC system from Agilent Technologies (Palo Alto, CA, USA) was used. An electrospray probe was operated in the negative mode with -4000 $\mathrm{V}$ and desolvation temperature was $350^{\circ} \mathrm{C}$. Samples were injected onto an ACE C18 (2.0 mm i.d. $\times 150$ $\mathrm{mm}$ length, $3 \mathrm{~mm}$ ) column with a guard column of the same phase. Mobile phases consisted of $50 \mathrm{mM}$ ammonium acetate $(\mathrm{pH} 4.5)$ as solvent $\mathrm{A}$ and methanol as solvent B. The separation was achieved by isocratic elution with $55 \% \mathrm{~A}$ and $45 \% \mathrm{~B}$ at a flow rate of $0.2 \mathrm{~mL} / \mathrm{min}$. For quantitative analysis, the mass spectrometer was operated in the negative mode with selected reaction monitoring mode (SRM); dissociation channels of $[\mathrm{M}-\mathrm{H}]$ to $\left[\mathrm{M}-\mathrm{CO}_{2} \mathrm{H}\right]^{-}$ions of sorbic acid and its isotope analogue at $\mathrm{m} / \mathrm{z} 111 \rightarrow 67$ and $\mathrm{m} / \mathrm{z}$ $113 \rightarrow 68$, respectively. For the SRM mode, a collision cell was filled with nitrogen gas at a pressure of $\sim 0.2$ $\mathrm{Pa}\left(\sim 2.0 \times 10^{-3} \mathrm{mbar}\right)$ and the collision energy was $-10 \mathrm{eV}$.

\subsection{Calculations}

The mathematical model for IDMS measurement of an analyte by one point calibration (with isotope-ratio matching) can be written as

$$
\mathrm{C}_{\text {sample }}=\frac{\mathrm{M}_{\mathrm{is- \text {sol,spiked }}} \cdot \mathrm{AR}_{\text {sample }} \cdot \mathrm{M}_{\mathrm{s}-\mathrm{sol}, \text { mix. }} \cdot \mathrm{C}_{\mathrm{s}-\mathrm{sol}}}{\mathrm{M}_{\text {sample }} \cdot \mathrm{AR}_{\text {std.mix. }} \cdot \mathrm{M}_{\mathrm{is}-\text { sol,mix. }}}
$$

\begin{tabular}{|c|c|}
\hline$C_{\text {sample }}$ & $\begin{array}{l}\text { is the concentration of sorbic acid in the } \\
\text { sample; }\end{array}$ \\
\hline$C_{\mathrm{s} \text {-sol }}$ & $\begin{array}{l}\text { is the concentration of the sorbic acid } \\
\text { standard solution; }\end{array}$ \\
\hline$M_{\text {sample }}$ & $\begin{array}{l}\text { is the mass of the sample taken for } \\
\text { analysis; }\end{array}$ \\
\hline$M_{\text {is-sol, spiked }}$ & $\begin{array}{l}\text { is the mass of the }{ }^{13} \mathrm{C}_{2} \text {-sorbic acid } \\
\text { standard solution added to the sample } \\
\text { aliquot; }\end{array}$ \\
\hline$M_{\mathrm{is}-\mathrm{sol}, \text { std. } \mathrm{r}}$ & $\begin{array}{l}\text { x. is the mass of the }{ }^{13} \mathrm{C}_{2} \text {-sorbic acid } \\
\text { standard solution added to the isotope } \\
\text { ratio standard solution; }\end{array}$ \\
\hline$M_{\mathrm{s} \text {-sol, std. m }}$ & $\begin{array}{l}\text { is the mass of the sorbic acid standard } \\
\text { solution added to the isotope ratio } \\
\text { standard solution; }\end{array}$ \\
\hline$A R_{\text {sample }}$ & $\begin{array}{l}\text { is the area ratio of sorbic acid } /{ }^{13} \mathrm{C}_{2} \text {-sorbic } \\
\text { acid for sample extract, observed by LC/ } \\
\text { MS; }\end{array}$ \\
\hline$A R_{\text {std. mix. }}$ & $\begin{array}{l}\text { is the area ratio of sorbic acid } /{ }^{13} \mathrm{C}_{2} \text {-sorbic } \\
\text { acid for the isotope ratio standard solution, } \\
\text { observed by LC/MS. }\end{array}$ \\
\hline
\end{tabular}

\section{Results}

\subsection{Optimization for ID-LC/MS method}

Structures of Sorbic acid and ${ }^{13} \mathrm{C}_{2}$-sorbic acid were illustrated in Fig. 1. As ${ }^{13} \mathrm{C}_{2}$-sorbic acid was a custom product, we carefully examined their mass spectra at the level of $1 \mathrm{mg} / \mathrm{kg}$ for sorbic acid and ${ }^{13} \mathrm{C}_{2}$-sorbic acid (Fig. 2(a) and (b)) in methanol. As shown in Fig. 2(b), there were no serious impurity peaks in mass spectrum of ${ }^{13} \mathrm{C}_{2}$-sorbic acid. The [M$\mathrm{H}]^{-}$peak of sorbic acid at $\mathrm{m} / z 111$ and ${ }^{13} \mathrm{C}_{2}$-sorbic acid at $\mathrm{m} / \mathrm{z} 113$ were dominant in the corresponding spectra. Fig. 2(c, d) shows the MS/MS mass spectra by CID (collision induced dissociation) for $[\mathrm{M}-\mathrm{H}]^{-}$

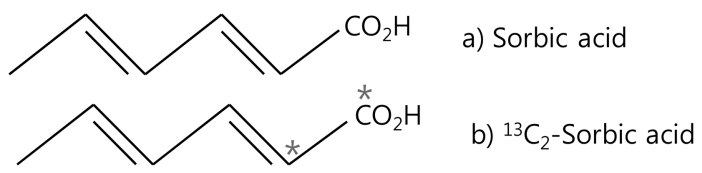

Fig. 1. Structures of sorbic acid and custom-synthesized ${ }^{13} \mathrm{C}_{2}$-sorbic acid (* is the position of ${ }^{13} \mathrm{C}$ of sorbic acid isotope analogue). 

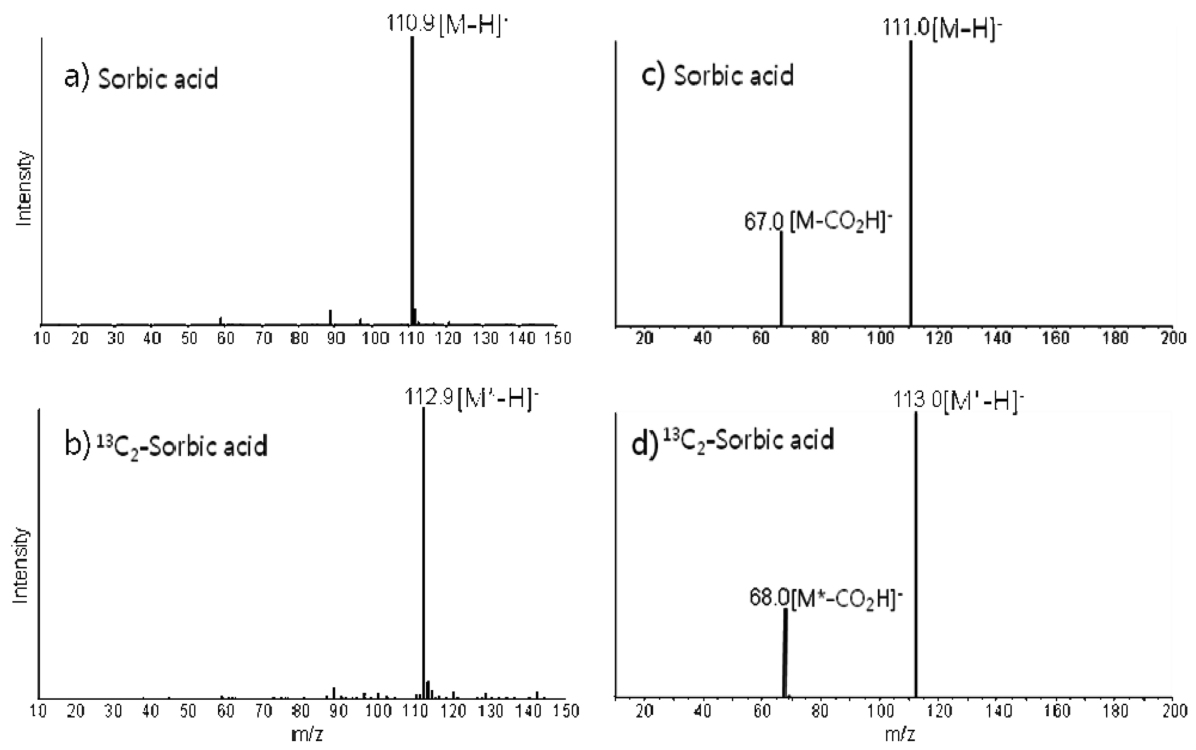

Fig. 2. MS spectra of $1 \mathrm{mg} / \mathrm{kg}$ sorbic acid (a) and ${ }^{13} \mathrm{C}_{2}$-sorbic acid (b) standard solution with negative electrospray ionization mode and MS/MS spectra of their $[\mathrm{M}-\mathrm{H}]^{-}$ions (c) and (d), respectively.
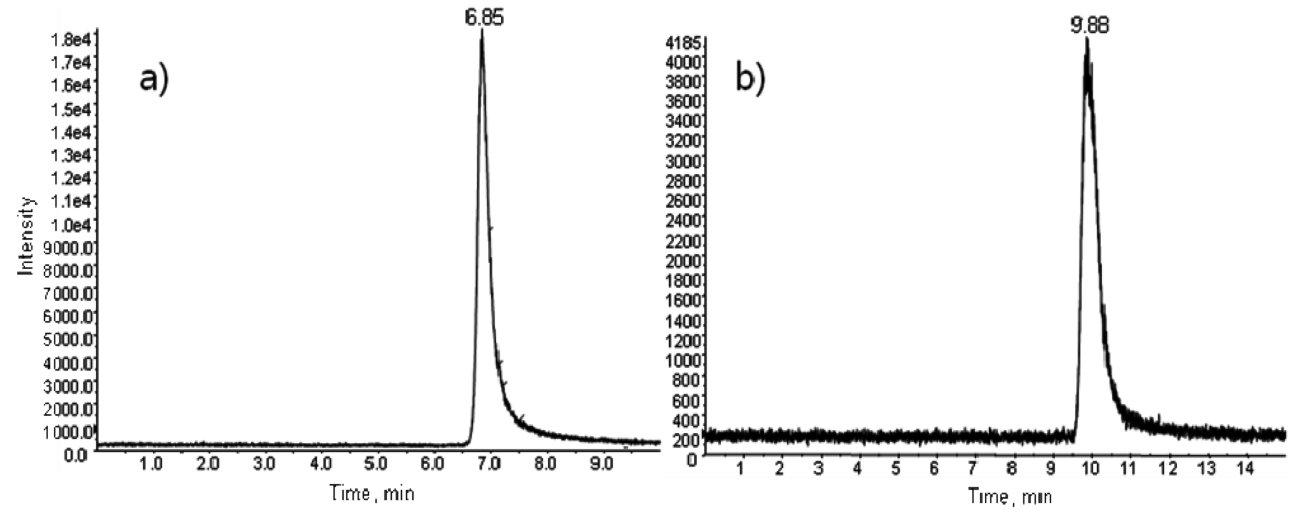

Fig. 3. Chromatograms in selected reaction monitoring (SRM) mode of $50 \mathrm{mg} / \mathrm{kg}$ sorbic acid with ammonium acetate buffer at $\mathrm{pH} 4.5$ (a) and at $\mathrm{pH} 4.0$ (b) as aqueous mobile phase.

at $m / z 111$ for sorbic acid and at $m / z 113$ for ${ }^{13} \mathrm{C}_{2^{-}}$ sorbic acid. The collision energy, $10 \mathrm{eV}$, for the highest sensitivity of fragment ions in the SRM mode still provided dominant portions of parent ions at $\mathrm{m} / \mathrm{z} 111$ and 113 (Fig. 2(c, d)). Higher collision energy for reducing of sensitivity for detecting parent ions induced the loss of sensitivity of fragment ions with the SRM mode.

LC separation conditions were optimized considering dissociation of sorbic acid (pKa of sorbic acid is 4.75). Aqueous mobile phase with various $\mathrm{pH}$ level was tested. Fig. 3(a) and (b) showed LC/MS/MS chromatograms of sorbic acid with $50 \mathrm{mM}$ ammonium acetate solutions at $\mathrm{pH} 4.5$ and at $\mathrm{pH} 4.0$, respectively. With pH 4.0 mobile phase solution, the sensitivity of sorbic acid decreased by ca. $50 \%$ and provided longer chromatographic retention compared to that obtained with $\mathrm{pH}$ 4.5. Thus, $50 \mathrm{mM}$ ammonium acetate solution at $\mathrm{pH} 4.5$ was used for the aqueous mobile phase as it provides adequate retention and reasonable ionization efficiency for the quantitation of sorbic acid. For organic mobile phase, methanol and acetonitrile were compared. Methanol was selected because acetonitrile did not provide appropriate 

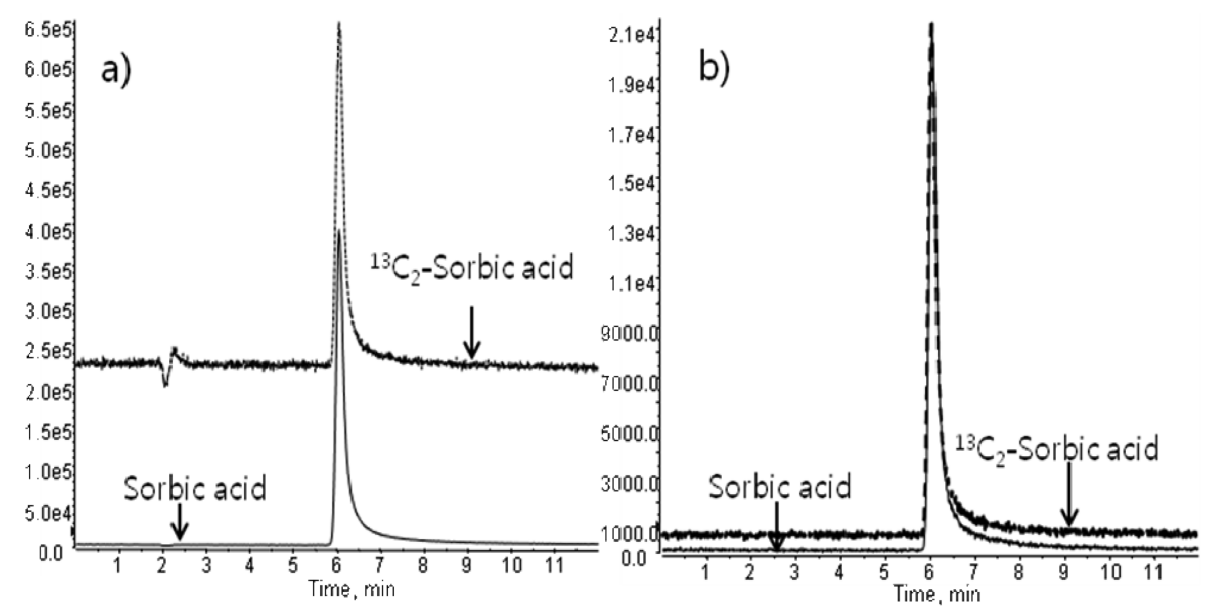

Fig. 4. Chromatograms in SIM mode (a) monitoring $[\mathrm{M}-\mathrm{H}]^{-}$at $\mathrm{m} / \mathrm{z} 111$ for sorbic acid (solid line) and at $\mathrm{m} / \mathrm{z}^{113}$ for ${ }^{13} \mathrm{C}_{2}-$ sorbic acid (dotted line) and SRM mode (b) monitoring at $\mathrm{m} / \mathrm{z} 111 \rightarrow 67$ for sorbic acid (solid line) and at $\mathrm{m} / \mathrm{z} 113 \rightarrow 68$ for ${ }^{13} \mathrm{C}_{2}$-sorbic acid (dotted line).
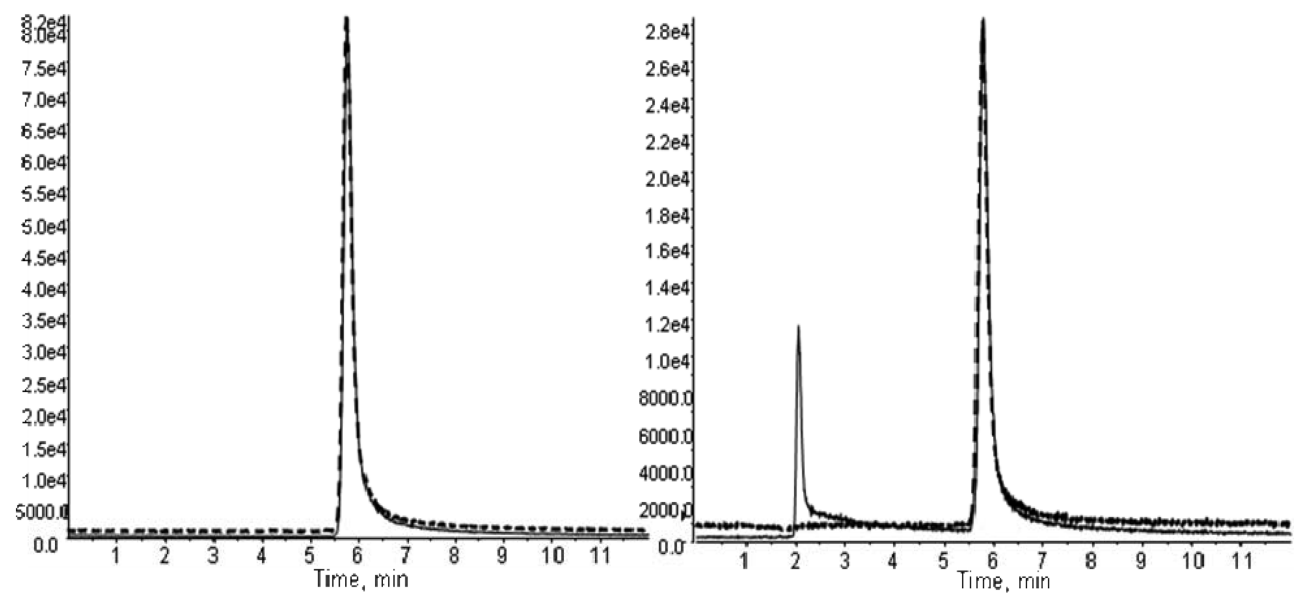

Fig. 5. Chromatograms in SRM mode of $200 \mathrm{mg} / \mathrm{kg}$ sorbic acid (solid line) and ${ }^{13} \mathrm{C}_{2}$-sorbic acid (dotted line) in isotope ratio standard solution (a) and in tea-drink sample (b).

retention with $\mathrm{C} 18$ column for sorbic acid.

Fig. 4(a) and (b) were chromatograms of single ion monitoring mode (SIM) and selected reaction monitoring mode (SRM), respectively for sorbic acid $(50 \mathrm{mg} / \mathrm{kg})$ and ${ }^{13} \mathrm{C}_{2}$-sorbic acid $(50 \mathrm{mg} / \mathrm{kg})$ in isotope ratio standard solution. Although the absolute intensity of SIM mode is stronger than that of SRM mode, the background of chromatogram for ${ }^{13} \mathrm{C}_{2}$-sorbic acid in SIM mode is much higher than that in SRM mode. The peak of $m / z 113$ in negative mode is one of the common background ions, which are attributed to trace amount of residual sodium formate cluster ions or trifluoroacetic acid ions. ${ }^{25-26}$ In the case of formate cluster ions, they can be easily contaminated in mass spectrometer by other organic solvents. Therefore, SRM mode was operated for the quantitative analysis of ID-LC/MS/MS measurement of sorbic acid in drink sample. Chromatograms of sorbic acid $(200 \mathrm{mg} / \mathrm{kg})$ and ${ }^{13} \mathrm{C}_{2}$-sorbic acid (200 $\mathrm{mg} / \mathrm{kg}$ ) in isotope ratio standard solution (a) and drink sample (b) are shown in Fig. 5. There are no significantly interfering peaks from sample matrix with the LC/MS/MS method. With those LC/MS/ MS conditions, the limit of detection for signal-to- 
Table 1. ID-LC/MS/MS results of gravimetrically fortified samples at the various levels of sorbic acid in teadrink

\begin{tabular}{ccc}
\hline \hline $\begin{array}{c}\text { Measured } \\
\text { concentration } \\
(\mathrm{mg} / \mathrm{kg})(\mathrm{n}=4)^{\mathrm{a}}\end{array}$ & $\begin{array}{c}\text { Fortified } \\
\text { concentration } \\
(\mathrm{mg} / \mathrm{kg})\end{array}$ & $\begin{array}{c}\text { Ratio } \\
(\%)^{\mathrm{c}}\end{array}$ \\
\hline $56.47 \pm 0.80^{\mathrm{d}}$ & 56.52 & 99.92 \\
$166.26 \pm 1.34$ & 166.26 & 98.60 \\
$414.25 \pm 3.25$ & 417.19 & 99.29 \\
$651.25 \pm 6.09$ & 648.48 & 100.43 \\
$797.76 \pm 6.35$ & 804.23 & 99.20 \\
\hline
\end{tabular}

a " $n$ " means the number of measurements.

${ }^{b}$ the uncertainty of the gravimetrically fortified level is rather minimal compared to the uncertainty in analytical measurement, thus is not reported in this table.

${ }^{\mathrm{c}}$ Ratio means that the difference ratio between measured concentration and fortified concentration.

${ }^{\mathrm{d}}$ The value after \pm means that the expanded uncertainty with a level of confidence of $95 \%$.

noise ratio of 3 was $0.5 \mathrm{mg} / \mathrm{kg}$ in SRM mode.

\subsection{Validation of method}

To validate the proposed method, gravimetrically fortified samples in the range of $50 \sim 800 \mathrm{mg} / \mathrm{kg}$ were prepared. The tea drink which was easily purchased from a local market was confirmed by the LC/MS/ MS method that the level of sorbic acid was below the detection limit. Table 1. is the LC/MS/MS results of sorbic acid in those fortified samples. The measurement results by LC/MS/MS agreed well with the fortified concentrations within their uncertainties.

In addition, another way to validate the analytical method is the use of certified reference materials (CRMs) or highly homogenized reference materials (RM). However, there are no CRMs for the analysis of sorbic acid in beverages to our knowledge, thus we prepared a batch of candidate reference material (ca. 600 bottles) in our laboratory by fortifying teadrink with sorbic acid to use it as a homogeneous sample for repeatability and reproducibility test. The procedure of preparation of the RMs for drink sample is described elsewhere. ${ }^{27-28}$

The reference value was determined with one sampling from each of ten bottles. The results are listed
Table 2. Results of sorbic acid in tea drink by ID-LC/MS/ MS in two different time periods within one month

\begin{tabular}{|c|c|c|}
\hline & Samples & $\begin{array}{c}\text { Concentration of } \\
\text { sorbic acid } \\
(\mathrm{mg} / \mathrm{kg})(\mathrm{n}=4)^{\mathrm{a}}\end{array}$ \\
\hline \multirow{13}{*}{ Period 1} & Sample \#1 & 195.0 \\
\hline & Sample \#2 & 204.6 \\
\hline & Sample \#3 & 215.9 \\
\hline & Sample \#4 & 205.8 \\
\hline & Sample \#5 & 221.0 \\
\hline & Sample \#6 & 207.7 \\
\hline & Sample \#7 & 214.0 \\
\hline & Sample \#8 & 202.2 \\
\hline & Sample \#9 & 198.9 \\
\hline & Sample \#10 & 208.0 \\
\hline & Average & 207.3 \\
\hline & RSTD & $3.8 \%$ \\
\hline & Expanded uncertainty ${ }^{\mathrm{b}}$ & 18.4 \\
\hline \multirow{7}{*}{ Period 2} & Sample \#1 & 216.4 \\
\hline & Sample \#2 & 201.0 \\
\hline & Sample \#3 & 215.0 \\
\hline & Sample \#4 & 212.2 \\
\hline & Average & 211.2 \\
\hline & RSTD & $3.3 \%$ \\
\hline & Expanded uncertainty ${ }^{\mathrm{b}}$ & 22.9 \\
\hline
\end{tabular}

a " $n$ " means the number of meaurements.

${ }^{\mathrm{b}}$ The expanded uncertainties are with a level of confidence of $95 \%$.

in Table 2. The reference value was $207.3 \pm 18.4 \mathrm{mg} /$ $\mathrm{kg}$ with the expanded uncertainty in $95 \%$ confidence level $(k=2.3)$. Details about the estimation of the reference value are described in our previous article, ${ }^{29}$ thus not described in here. The relative standard deviation among ten bottles was $3.8 \%$, indicating that the method has an appropriate repeatability. Reproducibility test was carried out with the same method after one month later by analyzing four bottles from the same RM batch. The value was $211.2 \pm 22.9 \mathrm{mg} / \mathrm{kg}$, which agreed within the initial reference value, indicating that the proposed method provided good reproducibility. The experiments with fortified samples at various levels of sorbic acid and the reference materials proved that the proposed method is reliable to determine the accurate amount of sorbic acid in drinks. 
Table 3. Sources of uncertainty for analysis of sorbic acid with ID-LC/MS/MS

\begin{tabular}{llc}
\hline \hline & \multicolumn{1}{c}{$\begin{array}{c}\text { Sources } \\
\text { (Evaluation methods) }\end{array}$} & $\begin{array}{c}\text { Typical value } \\
\text { (Relative \%) }\end{array}$ \\
\hline Sorbic acid standard solution & $\begin{array}{l}\text { Purity of the reference material (from the certificate) } \\
\text { Gravimetric preparation (from cross-check of independent } \\
\text { sets of calibration solutions) }\end{array}$ & $0.3 \%$ \\
\hline Calibration standard mixture & $\begin{array}{l}\text { Gravimetric mixing (from cross-check of independent sets } \\
\text { of calibration standard mixtures) }\end{array}$ & $0.14 \%$ \\
\hline Weights of sample taken for analysis & $\begin{array}{l}\text { Readability and linearity of the balance used (from the cer- } \\
\text { tificate of the balance) }\end{array}$ & $<0.01 \%$ \\
\hline $\begin{array}{l}\text { Weights of }{ }^{13} \mathrm{C}_{2} \text { - sorbic acid solution spiked into } \\
\text { sample taken for analysis }\end{array}$ & $\begin{array}{l}\text { Readability and linearity of the balance used (from the cer- } \\
\text { tificate of the balance) }\end{array}$ & $<0.01 \%$ \\
\hline $\begin{array}{l}\text { Peak area ratio of sorbic acid and }{ }^{13} \mathrm{C}_{2} \text {-sorbic acid } \\
\text { from LC/MS/MS measurements of calibration stan- } \\
\text { dard solution }\end{array}$ & Standard deviation of multiple measurements \\
\hline $\begin{array}{l}\text { Peak area ratio of sorbic acid and }{ }^{13} \mathrm{C}_{2} \text {-sorbic acid } \\
\text { from LC/MS/MS measurements of drink sample }\end{array}$ & Standard deviation of multiple measurements & $0.50 \%$ \\
\hline
\end{tabular}

\subsection{Sources of uncertainty}

As a full description for uncertainty is beyond the scope of this article, only brief one is given here. Details on the evaluation of uncertainty were described in our prior studies..$^{30-31}$ Table 3. lists sources of uncertainty in measurements of sorbic acid in teadrinks (RM batch) using ID-LC/MS/MS. Purity of the sorbic acid provided from its certificate works as a systematic uncertainty throughout this study. In addition, gravimetric preparation of standard solution, gravimetric mixing of isotope ratio mixture and the deviation of multiple measurement of isotope ratio standard solution are categorized as a systematic uncertainty. Although readability and linearity of the balance used for weighing sample and ${ }^{13} \mathrm{C}_{2}$-sorbic solution would be a part of random uncertainty, it is insignificant not to effect on the overall uncertainty. The standard deviation of multiple measurements among ten bottles is categorized as a random uncertainty $3.8 \%$ which is assumed to be contributed by the repeatability of the measurement method and sample inhomogeniety. The expanded uncertainty was obtained by combining random and systematic uncertainties with $95 \%$ confidence level.

\section{Conclusions}

An isotope dilution mass spectrometric (ID-MS) method based on LC/MS/MS was established for accurate and simple determination of sorbic acid in drink sample. The ID-LC/MS/MS method was performed with ${ }^{13} \mathrm{C}_{2}$-sorbic acid. The conditions of mobile phases were optimized for appropriate retention and separation of sorbic acid with a C18 column. The best performance was accomplished with 50 $\mathrm{mM}$ ammonium acetate ( $\mathrm{pH} 4.5)$ and methanol. The measurement results agreed with the gravimetrically fortified values at the various levels, which showed that the proposed method is appropriate for the analysis of sorbic acid in drink sample. The repeatability and the reproducibility test were carried out with the prepared reference materials in our laboratory. The repeatability test was performed with ten bottles and the relative standard deviation was $3.8 \%$. The reproducibility test was performed after one month later with the same method and results were agreed within their uncertainty. Those analytical results proved that the ID-LC/MS/MS method for sorbic acid analysis is reliable and reproducible. 


\section{References}

1. P.E. Hartman, Environ. Mutagen., 5, 217-222 (1983).

2. R. Munzer, C. Guigas and H. W. Renner, Food Chem Toxicol., 28, 397-401 (1990).

3. C. Ferrand, F. Marc, P. Fritsch and P. Cassand, Food addit. Contam., 17, 895-901 (2000).

4. C. Ferrand, F. Marc, P. Fritsch, P. Cassand and G. de Saint Blandquat, J. Agric. Food Chem., 48, 3605-3610 (2000)

5. D. Sochin and J. J. Leyden, J. Am. Acad. Dermatol., 14, 234-241 (1986).

6. O. W. Lau and S. F. Luk, Analyst, 114, 1269-1272 (1987)

7. G. Wilamowski, J. Assoc. Official Anal. Chem., 54, 663665 (1971).

8. O. W. Lau, S. F. Luk and Y. M. Cheung, Analyst, 114, 1047-1051 (1989).

9. T. Renner, N. Baer-Koetzle and G. Scherer, J. Chromatogr. A, 847, 127-133 (1999).

10. N. Ochiai, K. Sasamoto, M. Takino, S. Yamashita, S. Daishima, A. C. Heiden and A. Hoffmann, Anal. Bioanal. Chem., 373, 56-63 (2002).

11. M. M. Villiers and J. J. Bergh, Drug Dev. and Ind. Pharm., 26, 539-547 (2000).

12. I. M. P. L. V. O. Ferreira, E. Mendes, P. Brito and M. A. Ferreira, Food Res. Int., 33, 113-117 (2000).

13. S. A. V. Tfouni and M. C. F. Toledo, Food Control., 13, 117-123 (2002).

14. I. Garcia, M. Cruz Ortiz, L. Sarabia, C. Bilches and E. Gredilla, J. Chromatogr. A, 992, 11-27 (2003).

15. F. J. M. Mota, I. M. P. L. V. O. Ferreira, S. C. Cunha, M. Beatriz and P. P. Oliveira, Food Chem., 82, 469-473 (2003)
16. A. El-Gindy, F. El-Yazby, A. Mostafa and M. M. Maher, J. Pharm. Biomed. Analysis, 35, 703-713 (2004).

17. S. Negri, R. Bono, L. Maestri, S. Ghittori and M. Imbriani, Chem.-Biol. Interact., 153-154, 243-246 (2005).

18. B. Saad, Md. F. Bari, M. I. Saleh, K. Ahmad and M. K. M. Talib, J. Chromatogr. A, 1073, 393-397 (2005).

19. Z. Dobiasova, J. Pazourek and J. Havel, Electrophoresis, 23, 263-267 (2002).

20. Y. Tang and M. Wu, Talanta, 65, 794-798 (2005).

21. G. Dube, A. Herion and W. Richter, Metrologia, 34, 8386 (1997).

22. P. de Bivere, Anal. Proc., 30, 328-333 (1993).

23. K. G. Heumann, J. Mass Spectrom. Rev., 11, 41-67 (1992).

24. A. P. de Lennheer and L. M. Thienpont, Int. J. Mass Spectrom. Rev., 11, 249-307 (1992).

25. V. Barwick, J. Langley, T. Mallet, B. Stein and K. Webb 'Best Practice Guide for Generating Mass Spectra', LGC, Middlesex, 2007.

26. X. Xiang, C. Y. Ko and H. Y. Guh, Anal. Chem., 68, 3726-3731 (1996).

27. I. Lee, S. Ahn, B. Kim, E. Hwang and Y.-S. Kim, Bull. Korean Chem. Soc., 29, 2125-2128 (2008).

28. Y. Lee, B. Kim, J. Kim and S. Ahn, Mass Spectrom. Letters, 2, 37-40 (2011).

29. B. Kim, S. Park, I. Lee, Y. Lim, E. Hwang and H.-Y. So, Anal. Bioanal. Chem., 398, 1035-1042 (2010).

30. BIPM, IEC, IFCC, ISO, IUPAC and OIML Guide to the Expression of Uncertainty in Measurement (Geneva, Switzerland: International Organization for Standardization) ISBN 92-67-10188-9 1995).

31. B. Kim, E. Hwang, H.-Y. So and E. K. Son, Bull. Korean Chem. Soc., 31, 3139-3144 (2010). 